This is the version of the article accepted for publication in Indian Law Review published by Taylor \& Francis: https://www.tandfonline.com/loi/rilw20

Accepted version downloaded from soas research online: http://eprints.soas.ac.uk/29976

\title{
MODEL GROUNDWATER (SUSTAINABLE MANAGEMENT) BILL, 2017: A NEW PARADIGM FOR GROUNDWATER REGULATION
}

\author{
Philippe Cullet* \\ 2/3 Indian Law Review (forthcoming 2018)
}

\section{INTRODUCTION}

Groundwater has turned over the past half century into the most important source of water for most water uses in India. This fast increase is linked in part to the decentralised manner in which it can be accessed and to the fact that access does not necessarily depend on massive state investments. Today, groundwater is the backbone of India's food security and drinking water security. It accounts for around 60 percent of irrigation water use and 80 percent of drinking water needs. ${ }^{1}$

The importance of groundwater in practice is not reflected in water law. Indeed, most water laws focus on surface water. In particular, irrigation acts are overwhelmingly focused on the needs of surface irrigation, including relatively recent ones. ${ }^{2}$ Regulation of groundwater use has not been absent but since existing rights were defined in the case law, ${ }^{3}$ it has often been assumed that it is not regulated. The statutory frameworks concerning groundwater that exist are limited to laws adopted over the past twenty years that essentially introduce a level of topdown regulatory control over use of groundwater but do not provide a comprehensive regulatory framework. Further, they leave the underlying rights framework for accessing groundwater untouched.

* Professor of International and Environmental Law, SOAS University of London \& Senior Visiting Fellow, Centre for Policy Research, Delhi. The author was the Convenor of the 2011 Planning Commission of India's Sub-group drafting the Model Bill for Conservation Protection and Regulation of Ground Water, 2011 and a Member of the 2015-2017 Ministry of Water Resources, River Development \& Ganga Rejuvenation's Committee to Redraft the Draft Model Bill for Conservation Protection and Regulation of Groundwater, 2011.

$1 \quad$ P.S. Vijay Shankar, Himanshu Kulkarni \& Sunderrajan Krishnan, 'India's Groundwater Challenge and the Way Forward' [2011] 46/2 Econ \& Pol Wkly 37 and Planning Commission, An Approach to the Twelfth Five Year Plan (2012-2017).

2 eg Bihar Irrigation Act, 1997.

$3 \quad$ See text at notes 36 to 38 . 
The basic rules of access to groundwater that give landowners a de facto monopoly over its use have encouraged overexploitation by those with the financial means to dig further down. ${ }^{4}$ This has also ensured that governments have found it increasingly difficult to address the issue of over-use because it threatens politically powerful communities who benefit from the regime in place and use it to their own benefit. In a context of fast increasing use of groundwater, this has led to a situation where a majority of districts in India have problems related either to quantitative availability or to quality of groundwater or both. ${ }^{5}$ This crisis has a strong social equity dimension in a context where rural land ownership remains very unequally distributed with 73.17 percent of rural households being marginal landowners, that is owning less than one hectare of land. ${ }^{6}$

The overall result has been a situation where the crisis of groundwater is now widely acknowledged but where policy-making has been largely paralysed because falling water tables do not strike popular imagination in the same way that drying rivers and lakes do and because it is often politically easier to allow groundwater mining in the short term than to address longterm policy challenges. The outcome of this policy paralysis is that there is as yet no legal instrument that regulates groundwater comprehensively at aquifer level and in particular no instrument that effectively prioritises protection rather than simply regulate different uses. It is in this context that the Planning Commission in 2011 and the Ministry of Water Resources, River Development \& Ganga Rejuvenation in 2015 took up the challenge of drafting a new model legislation for groundwater. This reform initiative is crucial insofar as the present regulatory framework is unsuited to address the challenges facing the sector.

\section{CONTEXT FOR GROUNDWATER LAW REFORM IN INDIA}

Groundwater is the lifeline for most people in India, without which they would not get access to drinking water, let alone other domestic needs. Indeed, for decades, the use of groundwater in preference to surface water has been promoted because it was perceived as being safer and more easily accessible locally. This would not have led to depletion of water tables in most places barring the driest but the tremendous increase in groundwater use for irrigation and progressively for industry has led to a situation where aquifers are drying up or the quality of the water is decreasing due to anthropogenic or naturogenic causes, or both. ${ }^{7}$

Mining of groundwater was a partly 'silent' crisis for a number of years. Policy-makers and groundwater users were aware that water tables were falling because of over-exploitation. Yet, since falling water tables are not as emotive as dry riverbeds, an unholy alliance progressively took shape whereby the state could buy itself time by simply avoiding the subject and letting

4 Cf David Groenfeldt, Water Ethics - A Values Approach to Solving the Water Crisis (Routledge, 2014) 59 mentioning that by treating groundwater as an individual property right 'the legal cards are stacked against local sustainable management solutions'.

5 Planning Commission, Mid-Term Appraisal - Eleventh Five Year Plan 2007-2012 (New Delhi: Oxford University Press, 2011).

$6 \quad$ Ministry of Statistics and Programme Implementation, Household Ownership and Operational Holdings in India (Report No. 571, NSS 70 th Round, January-December 2013) Statement 5.3.

7 eg Vasant P. Gandhi and Vaibhav Bhamoriya, 'Groundwater Irrigation in India - Growth, Challenges, and Risks', in Infrastructure Development Finance Company ed., India Infrastructure Report 2011 - Water: Policy and Performance for Sustainable Development (New Delhi: Oxford University Press, 2011) 90. 
landowners pump as much as they wanted in accordance with the existing legal regime or by encouraging groundwater use, for instance, through energy subsidies. ${ }^{8}$

In recent times, it has become much more difficult for policy-makers to ignore the groundwater crisis. This is due to the fact that in many places, aquifers are so depleted that carrying on with the policy of ever deepening of groundwater structures is simply not tenable anymore. In addition, in many places, digging ever further has come at the cost of pumping water that is not safe for human consumption, ${ }^{9}$ leading to a policy reversal whereby the State of Rajasthan is planning, for instance, massive surface water drinking water schemes to address the reduction in availability of safe groundwater. ${ }^{10}$

The limited legal interventions of Indian states in the groundwater sector can be explained by a number of factors. Firstly, for more than a century and a half, landowners have enjoyed essentially unlimited control over groundwater found under their land. ${ }^{11}$ Even though the state does not recognise this as a right of ownership, this is how it is understood by people. The more this system is entrenched, the more landowners believe that they are entitled to doing whatever they want with this resource they see as their own. Secondly, the increase in groundwater use made possible by mechanical pumping has allowed the state to avoid a water crisis that would have hit many parts of the country decades ago if it had kept relying mostly on surface water for its water needs. Politicians are thus weary of doing anything too drastic until it becomes absolutely impossible not to take action or to be seen to take action. ${ }^{12}$ Thirdly, there is no obvious basis for taking comprehensive measures to protect aquifers in the existing water law framework in the absence of framework legislation. ${ }^{13}$ Indeed, water law is primarily focused on surface water and even recent water laws fail to integrate the lessons of the development of environmental law. As a result, the limited protection measures that exist are environmental measures that are separate from the water law framework.

Existing responses to the groundwater crisis reflect the complexity of the underlying situation. The legal framework is clear insofar as it gives landowners ownership-like rights. At the same time, the legal framework is patchy because groundwater is only addressed through property rights in land. This implies that there is no scope for considering groundwater per se but only through the rights of landowners. Yet, since the rights that landowners have were defined mostly in case law, non-lawyers have sometimes understood the legal situation as being indeterminate. ${ }^{14}$ This explains why some economists have called for the 'introduction' of

8 eg Tushaar Shah, Sujata Das Chowdhury, 'Farm Power Policies and Groundwater Markets - Contrasting Gujarat with West Bengal (1990-2015)' [2017] 52/25-6 Econ \& Pol Wkly 39.

eg K. Brindha \& L. Elango, 'Fluoride in Groundwater: Causes, Implications and Mitigation Measures', in Stanley D. Monroy ed, Fluoride Properties, Applications and Environmental Management (Nova Science Publishers, 2011) 111. eg Special Correspondent, 'Raje Govt. Lobbying for River Interlinking Project', The Hindu (6 July 2018), 3.

11 See text at note 35 . Where legislation has been adopted, it generally remains largely dormant.

This gap would be filled in part by the adoption of the Draft National Water Framework Bill, 2016.

See next section for an exposition of the basic legal position on groundwater rights. 
property rights, for instance, to allow the development of markets in groundwater. ${ }^{15}$ At this juncture, formal groundwater markets cannot be introduced because this requires delinking land rights and water rights, something that has not been done in India. Yet, informal markets have existed for decades. They are based on the existing legal framework that allows each landowner to pump as much as they want, and to competitive deepening that gives some landowners preferential access to available groundwater. ${ }^{16}$

One of the roots of the existing groundwater crisis is thus the existing legal framework structured around a strong framework of rights linked to land ownership. Surprisingly, policymakers have not necessarily understood this factor in the measures they have proposed to address falling water tables. Thus, the World Bank suggested at the beginning of this decade that among the legal remedies proposed was 'establishing property rights in water' ${ }^{17}$ This proposal was to delink water use rights from land rights and thus made in with the full knowledge that use rights are currently linked to land rights. Yet, using the word 'establish' seems to imply that this fills a gap and this is confirmed when the same report argues that 'the problem of groundwater overexploitation does not arise from inadequate legislation and therefore cannot be solved through legislative remedies'. ${ }^{18}$ The need to avoid starting from the perspective of an absence of property rights had, however, been made earlier in the literature. ${ }^{19}$

The idea that legislative remedies are not the answer to the groundwater crisis leads to the argument sometimes made that legislation is not the answer to the groundwater crisis. ${ }^{20}$ The basic idea is that there are far too many groundwater structures in India and that unlike in some other countries, it is not possible to have an effective top-down regulation of access points. ${ }^{21}$ It is then unsurprising to find that the limited measures put in place to address over-use of groundwater have been limited to attempting to indirectly control the use that individual landowners make of 'their' groundwater. This includes reducing or eliminating electricity subsidies and metering irrigation wells, measures seen as sufficient to resolve ' $[\mathrm{m}]$ ost of India's

15 eg Rebecca Nelson \& Meg Case, Taking Policy from Paper to the Pump: Lessons on Effective and Flexible Groundwater Policy and Management from the Western U.S. and Australia (Stanford, CA: Comparative Groundwater Law and Policy Program, 2013) v.

16 Existing informal markets do not function according to the paradigm for formal markets since there are no physical or legal limitations on the use of water. Cf. Richael K. Young, Smart Markets for Groundwater Trading in Western Nebraska: The Twin Platte - A Case Study for the Political Economy of Water Markets Project (Portland, OR: AMP Insights, 2016) 4.

17 World Bank, Deep Wells and Prudence - Towards Pragmatic Action for Addressing Groundwater Overexploitation in India (Washington, DC: World Bank, 2010) 47. ibid 48. 2010) 201. 
groundwater anomalies' quickly. ${ }^{22}$ This has been done successfully in Gujarat and some other states by separating electricity lines for irrigation and domestic consumption. ${ }^{23}$ On the whole, measures to reduce groundwater use have proved useful but they neither address the problematic nexus between land ownership and groundwater exploitation nor the protection of groundwater at aquifer level. In fact, most existing measures focus on individual access points and use of groundwater.

The distrust for groundwater legislation can be explained by different factors. Foremost among them is that no one seems to have mustered the courage to break the link between landownership and use of groundwater, despite the fact that this benefits mostly large landowners and excludes all landless from asserting any rights to groundwater, even though the realisation of their fundamental right to water is also dependent on access to groundwater. This inability to act is what is indirectly reflected in the 2007 Report of the Expert Group of the Planning Commission of India arguing that there is no need for 'change in basic legal regime relating to ownership/use rights' ${ }^{24}$ The problem is that in this case, the position is built around an incorrect understanding of the law where the Expert Group states that there 'are limits to an individual's right to exploit ground water', ${ }^{25}$ whereas the legal position that still holds in India is that there is no such limit. ${ }^{26}$

There has also been some misunderstanding of the structure of the law. Indeed, comprehensive groundwater legislation is not necessarily akin to 'blanket groundwater regulations' ${ }^{27}$ This is in fact enshrined in the constitutional framework that gives states the mandate over (ground)water to ensure that regional specificities can be built into state-level water laws. The fact that states have failed to make use of their legislative authority effectively, for instance, by failing to adapt model legislation to their specific needs and conditions as has happened with the old groundwater model bill, ${ }^{28}$ is symptomatic of a lack of law-making capacity at state level rather than of a structural problem.

The need for new groundwater legislation to address the groundwater crisis is borne out the inadequacy of existing groundwater rights and the limitations of the current framework that essentially only regulate uses of groundwater. The new framework should offer solutions to the present crisis. In a context where groundwater law has remained nearly stagnant for a century and a half, all that is necessary is essentially to update the law to reflect developments in the intervening period. Fortunately, there have been significant developments in Indian law

Tushaar Shah, 'Groundwater Management and Ownership: Rejoinder' [2008] 48/17 Econ \& Pol Wkly 116, 119.

eg Tushaar Shah \& Shilp Verma, 'Co-Management of Electricity and Groundwater: An Assessment of Gujarat's Jyotirgram Scheme’ (2008) 43/7 Econ \& Pol Wkly 59.

Ground Water Management and Ownership - Report of the Expert Group (New Delhi: Government of India, Planning Commission, September 2007) 41.

ibid 17.

Acton v Blundell (1843) 12 Meeson and Welsby 324 (Court of Exchequer Chamber, 1 January 1843).

Aditi Mukherji, Stuti Rawat and Tushaar Shah, 'Major Insights from India's Minor Irrigation Censuses: 1986-87 to 2006-07' [2013] 48/26-27 Econ \& Pol Wkly 115, 123. 
over the past few decades that new groundwater legislation can incorporate. This includes the recognition of the fundamental right to water by the Supreme Court of India in the early 1990 s. $^{29}$ In a context where the fundamental right is realised overwhelmingly through access to groundwater, it is essential that this should be reflected in legislation. The Supreme Court has also introduced various protection principles, ${ }^{30}$ which already apply in principle to water since water is part of environmental law, ${ }^{31}$ but that need to be integrated in water legislation. This is the case, for instance, the precautionary principle also recognised statutorily in the National Green Tribunal Act, 2010.32 Another significant development has been the constitutional mandate for decentralisation adopted in the 1990s and taken forward in most states. ${ }^{33}$ In this context, most states have already given local bodies, such as panchayats, control over water. The next step is thus simply to make this a reality in the specific context of groundwater in statutory form and to do this on the basis of the principle of subsidiarity to reflect that groundwater is the most local source of water. Groundwater legislation also needs to reflect existing environmental legislation that already addresses some aspects of water pollution but needs to be more specific groundwater context. ${ }^{34}$ With this background in mind, the next section analyses in more detail the existing legal framework for groundwater before turning to an examination of the proposed Groundwater (Sustainable Management) Bill, 2017.

\section{EXISTING LEGAL FRAMEWORK: LIMITED AND INADEQUATE}

Water rights have been linked to land ownership for many years, but surface water rights have generally been construed as usufructuary rights in recognition of the fact that flowing water is not amenable to appropriation in the same way as other natural resources. ${ }^{35}$ In addition, there has been for centuries an understanding that water should not be appropriated by any one individual because of its importance in ensuring human survival. For groundwater, at the point at which existing rules were set in the nineteenth century, insufficient understanding of hydrogeology led judges to decide that while ownership could not be granted to landowners, the rights granted would amount to full control over the resource. ${ }^{36}$ In fact, judicial strictures went further insofar as they specifically provided that an individual landowner could use groundwater, including to the extent of depriving their neighbours of their own share without attracting any penalty. ${ }^{37}$ One of the few limitations to have been placed on the rights of

Subhash Kumar v State of Bihar AIR 1991 SC 420 (Supreme Court of India, 1991).

Vellore Citizens' Welfare Forum v Union of India and Others (1996) 5 SCC 647 (Supreme Court of India, 1996).

Environment (Protection) Act, 1986.

National Green Tribunal Act, 2010, s 20.

Constitution of India, Arts 2436 \& 243W.

Water (Prevention and Control of Pollution) Act, 1974.

see generally Joshua Getzler, A History of Water Rights at Common Law (Oxford: Oxford University Press, 2004).

George Chasemore v Henry Richards (1859) VII House of Lords Cases 349 (House of Lords, 27 July 1859).

Acton v Blundell (1843) 12 Meeson and Welsby 324 (Court of Exchequer Chamber, 1 January 1843). 
landowners concerns the case where groundwater cannot be accessed without touching surface water in a defined surface channel. ${ }^{38}$ Further, where groundwater flows in defined channels, the rules applicable to surface water apply. ${ }^{39}$

The inappropriateness for India of the rules set up in the $19^{\text {th }}$ century became apparent relatively quickly. Already in 1930, in a case where appellants and respondents had relied on the main groundwater cases discussed above, Justice Wallace asserted that 'conditions in England are so different to those in the district of Bellary that I deprecate calling in aid English law on this subject'. ${ }^{40}$ Later on, the fast adoption of mechanical pumping in the 1960s led the government to take notice of the problem and to propose regulatory measures from 1970 onwards. Further measures were taken from the 1990s onwards with the court-mandated setting up of the Central Groundwater Authority. ${ }^{41}$ Yet, none of these efforts have addressed the core issues facing the groundwater sector.

The main effort undertaken to bring a statutory framework governing groundwater before the Model Groundwater (Sustainable Management) Bill, 2017 was the Model Bill to Regulate and Control the Development and Management of Ground Water, 1970. This was put forward by the Central Government to prod states into adopting legislation. This model legislation was then recast several times up to the last version of 2005. There was some evolution from 1970 to 2005 but the basic regulatory structure proposed remained unchanged.

The basic scheme of the Model Bill, 1970 was to provide for the establishment of a groundwater authority under the direct control of the government that was given the right to notify areas where it is deemed necessary to regulate and control the development and management of groundwater. In areas that are notified, groundwater users must apply for a permit from the authority, unless groundwater is to be drawn manually. ${ }^{42}$ The decision to grant or refuse a permit is taken in view of technical factors, such as spacing between groundwater structures and in view of the purpose for which groundwater is to be drawn. Surprisingly, there is no specific prioritisation for domestic use of water over other uses ${ }^{43}$ but drinking water needs are indirectly considered since, even in notified areas, hand-operated devices do not require a permit. ${ }^{44}$ In addition, a system of registration of wells throughout the state is also introduced. ${ }^{45}$

On the whole, the Model Bill, 1970 proposes a heavily top-down system that focuses on introducing new controls on groundwater use by individual landowners but entirely fails to take into account the need for aquifer-level protection measures. In addition, it fails to recognise

Grand Junction Canal Company v Shugar (1870-71) L.R. 6 Ch. App. 483 (Court of Appeal in Chancery, 17 January 1871).

BB Katiyar, Law of Easements and Licences (New Delhi: Universal Law Publishing, 13 ${ }^{\text {th }}$ ed 2010) 797.

Malyam Patel Basavana Gowd (dead) v Lakka Narayana Reddi AIR 1931 Mad 284 (High Court of Madras, 1930) para 8.

See text at note 47 .

Model Bill to Regulate and Control the Development and Management of Ground Water, 1970/2005, s 6. the only sub-section referring to drinking water, only considers it as an indirect factor.

ibid s 6(1).

45

ibid s 8 . 
that users include nearly every person in a given locality, rather than simply landowners, thus fails to take into account equity dimensions involved in groundwater use. It also fails to take into account that the regulation of some 32 million mechanised water extraction mechanisms that exist, ${ }^{46}$ can never be successfully achieved through centralised state-level measures.

The states that have introduced groundwater laws over the past two decades have all closely followed the model provided by the Model Bill, 1970. In the process, there has been little adaptation of the central framework to local state-specific conditions. These acts suffer from two major shortcomings: The first is that they are based on what is an outdated regulatory model not suited to address current groundwater challenges. The second is that the limited anecdotal evidence that exists indicates that these acts have usually been adopted at a point at which policy and political pressure had become sufficient to ensure enactment of legislation, but this is followed by uneven implementation.

The other major regulatory initiative concerning groundwater was taken at the central level and framed as environmental regulation. Upon directions of the Supreme Court, the Central Groundwater Authority (CGWA) was constituted 'to regulate and control, management and development of ground water in the country and to issue necessary regulatory directions for this purpose' ${ }^{47}$ The CGWA set up under the Environment (Protection) Act, 1986 has become the most visible face of groundwater regulatory interventions in the country. This is not linked to having a broad mandate for protecting and regulating water but mostly because there has been very little happening at the state level. The most immediate regulatory instrument of the CGWA are the Guidelines for issuance of No Objection Certificate (NOC) for groundwater withdrawal. ${ }^{48}$ These follow a similar conceptual framework as the one of the Model Bill, 1970 insofar as they propose a top-down regulatory framework whereby permission for groundwater use is accorded according to a number of set criteria upon application by the proposed user, with a basic distinction between notified areas where energised abstraction of groundwater can only be granted for drinking water and non-notified areas where industrial, infrastructure and mining projects can be considered according to criteria set out in the guidelines. ${ }^{49}$

Beyond the two major initiatives highlighted above, some states have gone for their own limited regulatory interventions. This is, for instance, the case of Punjab and Haryana that adopted in 2009 task-specific legislation focusing on prohibiting sowing and transplanting of paddy before specific dates in order to reduce groundwater use. ${ }^{50}$ This is important in a context where Punjab has been one of the few states consistently indicating that it does not believe comprehensive groundwater regulation is required. ${ }^{51}$ Even though the legislation adopted is

46

47

Tushaar Shah \& Sujata Das Chowdhury, 'Farm Power Policies and Groundwater Markets' [2017] 52/25-26 Econ \& Pol Wkly 39.

Ministry of Environment and Forests, Notification - Central Ground Water Authority, S.O. 38 (14 January 1997), as amended up to S.O. 1024 (6 November 2000).

48 Central Ground Water Authority, Guidelines for Issuance of No Objection Certificate (NOC) for Ground Water Withdrawal (With effect from 16.11.2015). Note that new guidelines have been proposed but not adopted yet.

ibid, s 2 \& 3.

Punjab Preservation of Subsoil Water Act, 2009 and Haryana Preservation of Sub-Soil Water Act, 2009.

Ground Water Management and Ownership - Report of the Expert Group (New Delhi: Government of India, Planning Commission, 2007) 29. 
very specific, it constitutes an acknowledgment that over-exploitation of groundwater cannot go on indefinitely without being addressed.

\section{MODEL GROUNDWATER (SUSTAINABLE MANAGEMENT) BILL, 2017: SALIENT FEATURES}

The Model Groundwater (Sustainable Management) Bill, 2017 (hereafter Groundwater Bill, 2017) constitutes an update of the Model Bill for the Conservation, Protection and Regulation of Groundwater, 2011.52 The drafting of the latter was triggered by the recognition in the Planning Commission's approach paper for the twelfth Five Year Plan that ' $[\mathrm{t}]$ here is an urgent need to come out with a clear legal framework governing the use of ground water'. ${ }^{53}$

The Groundwater Bill, 2017 seeks to provide a template for state-level groundwater regulation fitting the needs of a country overwhelmingly dependent on groundwater. It is informed by the groundwater situation and by existing constitutional provisions, decisions of the higher judiciary and developments on related areas of law, such as environmental law.

Firstly, the Groundwater Bill, 2017 extends the application of the doctrine of public trust to groundwater, following in this a worldwide trend. ${ }^{54}$ This has been clearly established for surface water for more than two decades by the higher judiciary, starting with a landmark decision of 1996.55 The question of whether the same status should be extended to groundwater is in principle non-controversial at this juncture. The Supreme Court has already declared groundwater to be covered by the public trust in at least one case, even if this was not a case focused on water. ${ }^{56}$ Further, there is no tenable reason to maintain the distinction between surface and groundwater that has been at the root of different legal regimes for the two types of water since the $19^{\text {th }}$ century. Indeed, the Draft National Water Framework Bill, 2016 specifically acknowledges the need to ensure integration of regulatory measures taken for surface and groundwater. ${ }^{57}$ The application of the doctrine of public trust to groundwater reflects its importance as the main source of water for most people's domestic and livelihood needs. There is a collective and individual dimension to this recognition since it is the welfare of individuals as well as communities that is directly dependent on access to groundwater and on protection of aquifers.

The recognition that groundwater is a public trust is a momentous change in a context where groundwater has essentially been seen as part of the private purview of landowners for many decades. At the same time, this recognition will have no impact on land rights per se and

52 Model Bill for the Conservation, Protection and Regulation of Groundwater, 2011

<http://www.planningcommission.nic.in/aboutus/committee/wrkgrp12/wr/wg_model_bill.pdf>

53 Planning Commission, An Approach to the Twelfth Five Year Plan (2012-2017), para 5.18. Similarly, see Department of Drinking Water and Sanitation - Rural Drinking Water, Strategic Plan 2011-2022 Ensuring Drinking Water Security in Rural India, 5(4)(2).

Kerstin Mechlem, Thematic Paper 6: Legal and Institutional Frameworks (Groundwater Governance: A Global Framework for Country Action, GEF ID 3726, 2012) 8. MC Mehta v Kamal Nath (1997) 1 SCC 388 (Supreme Court of India, 1996). 
landowners will still be essentially in control of access to groundwater. In practice, the main change will be that regulation will be conceived first from the perspective of the conservation needs of the aquifer, rather than only the atomised perspective of individual needs of individual landowners. Further, it will ensure that a community dimension can be introduced to the conservation and use of aquifers, something that has been completely missing until now.

The Groundwater Bill, 2017 also includes for the first time protection principles that have been applicable in environmental law for decades. This includes the very basic, but as yet not formalised in water law, prevention principle that provides that where environmental damage is foreseeable it should be prevented rather than addressed through compensation after damage has occurred. ${ }^{58}$ In addition, the Bill also specifically refers to the precautionary principle and polluter pays principle, thus giving groundwater regulation a strong environmental perspective. 59

Secondly, the Groundwater Bill, 2017 reflects the fact that groundwater is often seen as the most local source of water. Linked to this physical proximity in legal terms are the principles underlying the decentralisation reforms initiated in the 1990 s with the $73^{\text {rd }} / 74^{\text {th }}$ constitutional amendments. The Groundwater Bill, 2017 logically integrate these at the very centre of its regulatory scheme and proposes that groundwater regulation should be based on the subsidiarity principle as called for in the Draft National Water Framework Bill, 2016. ${ }^{60}$ This ties in with the recognition of groundwater as public trust and leads to the regulatory framework being centred around a bottom-up institutional structure wherein each level of government is called upon to act as the trustee at their respective level.

Thirdly, the Groundwater Bill, 2017 takes forward the need to translate into practice the recognition of the fundamental right to water by the higher judiciary from the early 1990s. ${ }^{61}$ This is a major step forward in a context where no water legislation has yet integrated the right to water to ensure that is realised through the implementation of statutory frameworks. ${ }^{62}$ Besides making the conceptual link, the Groundwater Bill, 2017 specifically provides that drinking water has the highest priority among competing groundwater uses. ${ }^{63}$ This should be unremarkable and is indeed what all actors implement in practice but it is an important legislative statement since no statute makes this priority clear yet. ${ }^{64}$ The Groundwater Bill, 2017 goes further in terms of ensuring that the right to water is linked with the realisation of other fundamental rights, in particular the rights to food, health and environment. With regard to the right to food, the prioritisation of water uses specifically provides that after drinking

Model Groundwater (Sustainable Management) Bill, 2017, s 7(2).

ibid, s 7(3).

Draft National Water Framework Bill, 2016, s 18.

Subhash Kumar v State of Bihar AIR 1991 SC 420 (Supreme Court of India, 1991).

Similarly, administrative directions, such as Ministry of Drinking Water Supply, National Rural Drinking Water Programme - Movement Towards Ensuring People's Drinking Water Security in Rural India Framework for Implementation (updated 2013) do not make the link. Model Groundwater (Sustainable Management) Bill, 2017, s 10. Water Policy, 2012 still maintains a priority for drinking water but has done away with the prioritisation that existed in earlier versions of the policy. 
water, it is water needed to achieve food security and sustaining sustenance agriculture that takes precedence. ${ }^{65}$ The link with the right to health is made by specifically linking quality standards with the proposed legislation. ${ }^{66}$ The right to environment is also clearly linked, if indirectly, for instance through the provision that any groundwater use should be "consistent with the objective of sustaining aquifers and ecosystems indispensable to the long-term maintenance of the resource' ${ }^{67}$

With regard to the institutional framework meant to oversee the implementation of the act, the Groundwater Bill, 2017 builds on existing institutions while providing a framework based on decentralisation and subsidiarity. It uses existing administrative boundaries that may not always coincide with that of the aquifer. This is a necessary compromise since groundwater protection and use must be linked to measures taken for surface water as well as other natural resources. Where an aquifer is shared by different local bodies, the Groundwater Bill, 2017 provides that the higher-level authority is given the authority to coordinate the framework.

In practice, the Groundwater Bill, 2017 provides that all local bodies (panchayats and municipalities) must have a committee specifically devoted to groundwater management. In rural areas, this is a sub-committee of the Village Water and Sanitation Committee and in urban areas a water management within which groundwater is included is to be set up. ${ }^{68}$ Beyond this, the Groundwater Bill, 2017 provides for a multi-tier institutional framework at the Block, District and State level, whereby the higher-level institutions are called upon to coordinate activities taken at the lower level, and to take decisions on matters that require coordination between more local institutions. For instance, the District Groundwater Council's functions include the consolidation of panchayat and municipal groundwater security plans into a District Groundwater Security Plan. ${ }^{69}$ The Council also coordinates the preparation of groundwater security plans for aquifers that are shared between panchayats and municipalities. ${ }^{70}$

The Groundwater Model Bill also breaks new ground in terms of the substantive regulatory measures proposed. Some of the main innovations it proposes are the introduction of groundwater protection zones and groundwater security plans. In other words, the Bill suggests that the most important dimension of groundwater regulation is the protection of aquifers in the short and long term. Protection zones are to be set up in situations where the aquifer needs to be protected from specific threats, such as land use pattern changes, where there are concerns related to groundwater-dependent livelihoods and where areas require specific regulatory measures, such as where arsenic or fluoride is present in the groundwater. ${ }^{71}$ These protection zones are meant to foster the sustainability of groundwater security plans that are the main instrument providing the trustee (appropriate government) an opportunity to plan conservation

Model Groundwater (Sustainable Management) Bill, 2017, s 10.

ibid, s 4(3).

ibid, s 10 proviso. 
and use of groundwater at the level of the whole administrative unit it covers. ${ }^{72}$ Groundwater security plans are meant to ensure availability of sufficient safe water for domestic and livelihood uses for every person, to ensure water security at all times, including in times of crisis, such as droughts or floods and to provide for measures to maintain and improve water quality. ${ }^{73}$ These plans are to be prepared for every watershed, administrative unit or aquifer and where the aquifer straddles more than one administrative unit, the District Groundwater Council helps the coordination of the preparation of such plans between administrative units sharing an aquifer. ${ }^{74}$

The Groundwater Bill, 2017 also addresses groundwater uses and specifically reflects the fact that different uses need to be regulated in different ways. It first acknowledges the increasingly crucial issue of inter-sectoral allocation by providing for a prioritisation of uses. ${ }^{75}$ It moves to link groundwater use with duties of users in recognition of the fact that all users, and particularly large-scale users, have a duty to avoid wastage and contamination, a duty to ensure conservation, a duty to take measures fostering replenishment or recharge, such as through afforestation/reforestation. ${ }^{76}$

These general obligations are complemented with provisions concerning the need to foster groundwater harvesting and catchment conservation, recycling and reuse, and prevention and mitigation of waterlogging. ${ }^{77}$ The Groundwater Bill, 2017 also devotes specific chapters to some of the main groundwater uses. Chapter VIII focuses on livelihoods and irrigation. It provides a right to water for livelihoods to the extent that this does not impact domestic needs. ${ }^{78}$ It then distinguishes small-scale irrigation from medium and major irrigation for which an authorisation system is introduced and for which a water rate has to be paid. It also provides that where a Groundwater Protection Zone has been set up, implying that there are specific threats to the aquifer, measures should be taken towards moving away from water-intensive cash crops. ${ }^{79}$

In Chapter IX, groundwater use for industries and infrastructure is specifically addressed. The Groundwater Bill, 2017 provides that such uses require an authorisation from the appropriate government valid for a period of five years. ${ }^{80}$ All industrial and bulk uses attract a water rate that may vary according to factors such as scarcity, pollution and prioritisation of use. ${ }^{81}$ The

ibid, s 11 .

73 ibid, s 11(2).

74 ibid, s 17(c).

75 ibid, s 10.

76 ibid, s 20.

77 ibid, s 21-3.

78 ibid, s 24.

79 ibid, s 24(6).

80 ibid, s 25(1) and (8).

81 ibid, s 26. 
Bill devotes a specific provision to mining, thereby being the first water legislation to specifically link mining regulation with water. ${ }^{82}$

The Groundwater Bill, 2017 also innovates in introducing for the first time in water law tools that have become standard practice in other fields of law. ${ }^{83}$ In particular, it integrates the concept of social and environmental impact assessment. ${ }^{84}$ Impact assessment was actually first introduced for water infrastructure, specifically for dams, in the late 1970s but it had not yet been enshrined in any water law. 85 The Bill thus builds on existing standards and applies them specifically to groundwater. Other tools borrowed from existing legislation in other fields include the provision on transparency systems and duties of proactive disclosure that build on the right to information legislation, ${ }^{86}$ and the introduction of social audits that have become a regular feature, though are a novelty in water law.

The last two substantive chapters of the Groundwater Bill, 2017 deal respectively with offences and penalties, and grievance redressal. In Chapter IX, relatively specific and stringent penalties are introduced to ensure that the substantive provisions of the act are effectively complied with. ${ }^{87}$ A series of civil and administrative remedies are also detailed, including for instance strict liability in case of substantial harm to groundwater quantity or quality by industrial or commercial users. ${ }^{88}$ Chapter $\mathrm{X}$ seeks to ensure that grievances can be solved as much as possible at the local level and through mediation and conciliation. ${ }^{89}$ It also provides for the appointment of a Groundwater Grievance Redressal Officer in each block and municipality who is given jurisdiction over all complaints arising under the act with the powers and obligations vested in a civil court. ${ }^{90}$ This is to ensure that justice can be delivered as close to the local level as possible by people who are conversant with local realities.

\section{THE GROUNDWATER MODEL BILL, 2017 AND BEYOND}

The Groundwater Bill, 2017 has the potential to engineer the significant changes that are desperately needed in the groundwater sector. Existing regulatory interventions have largely failed to tackle ever-increasing groundwater use, as confirmed by the increasing number of saline, semi-critical, critical and over-exploited blocks. ${ }^{91}$ This is in part because the points of

82

83

ibid, s 27.

Environment Impact Assessment Notification, 2006.

Model Groundwater (Sustainable Management) Bill, 2017, s 28.

eg Guidelines for Environmental Impact Assessment of River Valley Projects, 1985.

Model Groundwater (Sustainable Management) Bill, 2017, s 29-30.

ibid, s 32 .

ibid, s 33(11).

ibid, s 36 .

ibid, ss $37,40$.

See Central Ground Water Board, Dynamic Ground Water Resources of India (As on $31^{\text {st }}$ March 2013) (2017) and Central Ground Water Board, Dynamic Ground Water Resources of India (As on March 2004) (2006). 
intervention have been limited and because there has been no attempt to broaden the conceptual framework for regulation to the aquifer level.

At this juncture, the groundwater sector is the lifeline of India, particularly in the majority of states that are highly dependent on groundwater. It requires sustained interventions to update the legal framework so that it can address the needs and challenges that states are facing. This will also require the necessary political will to confront existing vested interests, something that various state governments have avoided doing for years in the hope that the silent crisis of groundwater depletion being largely invisible to the naked eye would not become a politically sensitive issue. We have now reached the stage in many states where there is no option but to take measures to protect what can still be protected.

The Groundwater Bill, 2017 is an excellent starting point for rethinking groundwater regulation. At the same time, it needs to be adapted by states before adoption by the state legislature, something that has not effectively happened in the past. In other words, the process does not stop at the drafting of model legislation at the centre but requires further legislative drafting in each state.

Besides, there is also a need for further broader consultations at the state level, something that has not happened yet. The Groundwater Bill, 2017 has benefitted from an open consultation in 2011 at the Planning Commission and from inputs from state governments and the NITI Aayog in 2015-2017. A consensus among policy-makers is thus progressively being found. At the same time, the opportunity for a broader process of consultation with a cross-section of groundwater users has not arisen yet. This should be built into the process of legislative drafting at the state level.

There are thus a number of additional steps that need to be taken to ensure that the specific legislation adopted by individual states reflects all the basic principles found in the Groundwater Bill, 2017 in a way that is informed by the specificities of the particular state. In a context where the success of the Groundwater Bill, 2017 will depend in large part on effective local institutions, particular attention will need to be given to states where bodies of local governance remain institutionally relatively weak. These are potentially significant challenges but they are no different than for the governance of all other natural resources at the local level and there is no reason to believe that laggard states cannot progressively strengthen their local democratic governance.

Overall, avoiding legal reform for groundwater law is not an option anymore. Previous reform efforts have been conceptually limited because they did not tackle the basic problem of landowners' monopoly control over groundwater, essentially top-down when the resource needs to be firstly protected and managed at the local level and have often side-lined the need for protection in favour of only allocating available groundwater among different users. The Groundwater Bill, 2017 provides a framework to address the infirmities of past reforms. It needs to be taken forward in a sensitive manner that recognises that different states within India face very different hydrological, environmental and social contexts. 